\title{
Short Index of Job Satisfaction: Validity evidence from Portugal and Brazil
}

\author{
Jorge Sinval $^{1,2}$, João Marôco $\mathbb{1}^{1}{ }^{*}$ \\ 1 William James Center for Research, ISPA—Instituto Universitário, Lisbon, Portugal, 2 Business Research \\ Unit (BRU-IUL), Instituto Universitário de Lisboa (ISCTE-IUL), Lisbon, Portugal \\ *.jpmaroco@ispa.pt
}

\section{Abstract}

Job satisfaction is an important construct that is known to be associated with workers' performance and wellbeing. As such, to properly measure it, one must use adapted measures that show adequate validity evidence for the desired context. Such measures should preferably be short to allow the parsimonious use of various measures/constructs in the same data collection. The aim of this paper is to adapt the Portuguese version for Brazil and Portugal of the Short Index of Job Satisfaction (SIJS). The SIJS is a psychometric instrument that measures job satisfaction through five items. A cross-sectional study was conducted with two multi-occupational workers samples, one from Brazil $(n=599)$ and one other from Portugal $(n=572)$. The SIJS presented good validity evidence based on its internal structure, namely dimensionality, reliability, and measurement invariance across countries and sexes. It also revealed to be positively correlated with work engagement, and quality of work life (convergent evidence). It also has shown to be negatively associated with burnout (discriminant evidence). The SIJS showed promising validity evidence. The SIJS can be useful to be used together with other instruments, due to its small number of items, producing data with good psychometric properties.

Published: April 14, 2020

Peer Review History: PLOS recognizes the benefits of transparency in the peer review process; therefore, we enable the publication of all of the content of peer review and author responses alongside final, published articles. The editorial history of this article is available here: https://doi.org/10.1371/journal.pone.0231474

Copyright: @ 2020 Sinval, Marôco. This is an open access article distributed under the terms of the Creative Commons Attribution License, which permits unrestricted use, distribution, and reproduction in any medium, provided the original author and source are credited.

Data Availability Statement: All relevant data are within the manuscript and its Supporting Information files.

Funding: JS and JM secured funding from the Portuguese Science Foundation (Grant number: UID/PSI/04810/2019) https://www.fct.pt/. This

\section{Introduction}

Job satisfaction has a long history of proliferating organizational research [1] being one of the most-if not the most-studied variables in business science [2]. It was brought into the limelight in the 30s $[3,4]$ being the most studied variable in the organizational behavior context $[5,6]$. It has various definitions. The most cited is the one provided by Locke [7], which considered job satisfaction as a positive emotional state that results from the worker's job associated experiences. Researchers can be interested in an overall measure of job satisfaction or particular job satisfaction facets, being the first usually preferred [8]. Overall job satisfaction can be seen as a formative construct, aggregating satisfaction with specific facets of the job [9]. Such approach appears as a solution to measure the overarching degree of satisfaction with various job attributes, coming with various different flavors [8].

Due to its complexity-influenced by various factors-this construct is frequently used in work and organizational studies together with other dimensions. The factors that influence job 
work was also produced with the support of Infraestrutura Nacional de Computação Distribuída (INCD); funded by Fundação para a Ciência e a Tecnologia (FCT) and Fundo Europeu de Desenvolvimento Regional (FEDER) under the project 22153-01/SAICT/2016).

Competing interests: The authors have declared that no competing interests exist. satisfaction can be considered both at the individual (mainly one's values, but also personality and mental health) and the organizational level (work, payment, promotions, peers/colleagues, supervisor, top leadership and benefits/policies) [7]. As such, a higher quality of work-life balance is expected to produce higher job satisfaction [10-12] while more job satisfaction is positively related to greater organizational commitment [13]. In the opposite direction, more stress in the workplace [14] and more surface acting [15] are related to less job satisfaction. It has been observed that workers have their job satisfaction levels decreasing parallel to the increasing tenure in a specific organization, while for people getting older-and transitioning of the organization-their satisfaction increases [16]. Lack of job satisfaction can lead to turnover [17-19], negative mood [20], reduced health and life happiness [7]. It can be related to several withdrawal behaviors [6] as absenteeism, presenteeism, and performance [21-24]. The relation with performance has long been considered the "holy grail" of satisfaction research [25] However, such relation is not unidirectional, lower performance can also lead to less job satisfaction [7]. It also has relations with several other job behaviors [26].

Despite existing many different psychometric instruments to measure the job satisfaction construct, some criticism has been made about the way this construct has been measured [27], since few of those instruments have shown satisfactory validity evidence [14]. Some of the most widespread measures are: the Index of Job Satisfaction [28] which also has a short version of five items (Short Index of Job Satisfaction [SIJS]) [29]; the Measure of Job Satisfaction (MJS) [30]; the Job in General Scale (JIG) [31] which is part of the Job Descriptive Index (JDI) [32]; the Andrew and Withey Job Satisfaction Questionnaire [33]; the Job Satisfaction Survey (JSS) [34]; the Minnesota Satisfaction Questionnaire [35]; the Michigan Organizational Assessment Questionnaire Job Satisfaction Subscale (MOAQ-JSS) [36]; and the Generic Job Satisfaction Scale (GJSS) [37]. Some of those measures are lengthy like the MJS (38 items) [30], the JIG with 18 items [31], the JSS with 36 items, or the MSQ with 100 items in the long-form, and with 20 items in the short form [35]. Other measures are shorter, like the SIJS (comprising five items), the MOAQ-JSS with three items, the Andrew and Withey Job Satisfaction with five items, or the GJSS with ten items. Van Saane et al. [14] reviewed several measures of job satisfaction and concluded that only seven of 29 reviewed measures fulfilled the authors' minimum criteria of an adequate instrument (i.e. internal consistency and validity evidence). In such a wide variety of measures, some are specific for a specific job (e.g. MJS was developed for nurses) while others can be used with multiple occupations (e.g. SIJS, JIG, JSS).

Some instruments measure job satisfaction as a unidimensional global measure, while others assume it a multidimensional construct. Examples of former are the SIJS, the JIG, the MOAQ-JSS or the Andrew and Withey Job Satisfaction Questionnaire. While the latter has as examples the MSQ, the GJSS, the JSS, or the MJS. Global measures are more parsimonious than multidimensional constructs. It is expected that the latter explains more variance, however, it might be difficult to sort out if the broader measure assures that it is measuring the construct, or if it is also measuring elements of its causal network [38]. If one aims to measure specific job satisfaction areas, the multidimensional instruments will be more useful, since they measure job satisfaction facets. Although, the global scales are useful to have a general measure of job satisfaction [31].

There are also single-item measures, which some authors find useful in specific situations [27,39] and which can be more cost-effective than multi-item measures [40]. Despite singleitem measures' usefulness and correlation with scale measures-from a psychometric perspective, multiple-item measures are preferable [41,42]. Single-item measures do not allow to obtain internal consistency estimates, using them to measure psychological constructs can be seen as a fatal error [43]. As such, short measures that approach job satisfaction from a general perspective-as the SIJS-without entering in the peculiarities and the specifics of certain 
occupations might be preferable to single-item measures. These short multi-item measures maintain the overall perspective of the measure with the advantage of obtaining the latent measure through the necessary multiple items. It is preferable to select a short measure that has demonstrated validity evidence in the desired population of the study, then to adapt or select some items of a longer instrument [44]. One of these short measures is the SIJS which has some advantages over other measures. It is freely available, has shown good psychometric properties and has been used in different cultures [45-48].

No studies adapting the SIJS to Portugal or Brazil were found, as such, the aim of this study is: i) adapt the SIJS in its Portuguese version for Brazil and Portugal and assess its validity evidence; and, ii) compare the job satisfaction levels between sexes and countries. Following the guidelines of the Standards for Educational and Psychological Testing [49] two of the possible five sources of validity evidence for psychological instruments will be analyzed. The first is based on the internal structure which refers to the reliability of the scores, dimensionality and measurement invariance. The second source of validity is based on relation to other variables. Regarding the validity evidence based on the internal structure, three hypotheses were defined. Previous studies suggest that the SIJS is a single-factor measure suitable to obtain a general job satisfaction measure, presenting satisfactory validity evidence [46,50,51]. Hypothesis 1 states that the SIJS maintains its original dimensionality (five items, one factor) supported by factorial validity evidence.

Various studies showed that the SIJS presents good reliability, namely, internal consistency estimates [52-55]. Hypothesis 2 assumes that the SIJS presents adequate evidence validity in terms of reliability of the scores.

No study was found testing measurement invariance of the SIJS between sexes or countries. Nevertheless, there is evidence that other psychological instruments used in the organizational context achieved measurement invariance among countries (i.e. Brazil and Portugal) and among sexes in the two countries [56,57]. Brazil and Portugal share more than the same language, they exchange culture and they share human capital. As such, it will be likely that the SIJS has measurement invariance between countries and sexes. Thus, Hypothesis 3 states that SIJS will hold measurement invariance (at least scalar invariance) among Brazil and Portugal, and sexes within each of the countries.

The second source of validity evidence, based on the relationships with other variables, will be checked using quality of work-life, burnout, and work engagement measures. Lack of Job satisfaction is expected to be a predictor of burnout [58-60]. On the other hand, work engagement has shown to predict job satisfaction [61-63] and by the quality of work-life [12]. Nevertheless, this source of evidence is intended to assure that job satisfaction is distinguished from associated concepts [64]. Altogether, Hypothesis 4 states that the SIJS shows adequate validity evidence based on the relation to other variables-more specifically-nomological evidence [65]. As such, it hypothesized that the SIJS will present discriminant evidence with burnout (Hypothesis 4.1), and convergent evidence with work engagement (Hypothesis 4.2) and quality of work-life (Hypothesis 4.3).

Previous research studied differences among sexes for job satisfaction among countries and sexes. The meaning attached to work seems to not differ significantly among countries [6]. However, Bozionelos and Kostopoulos [66] indicated that different countries might have differences in their job satisfaction levels. Such differences have been observed between several countries [67-69]. Pichler and Wallace [70] found that differences mainly result from composition and individual-level factors of each countries' workforce, instead of inherent cultural and historic characteristics. While, on the other hand, Hauff, Richter, and Tressin [71] indicated that some job characteristics vary significantly between countries, being partially moderated by cultural dimensions. It seems that culture might be a moderator between job 
satisfaction and job characteristics [72,73]. Given that Portugal and Brazil are two countries that share language and cultural features, it is expected that job satisfaction differences between countries are small or non-existent.

In terms of sex comparisons, the theoretical arguments behind potential workplace beliefs and attitudes among women and men are related to the work-life conflict [74]. Women are historically more affected by this conflict, and consequently, they might present a lower job satisfaction than men, particularly in some life events like the first marriage or the birth of the first child [75]. Nevertheless, women can present higher job satisfaction levels despite their poor quality of work conditions, something that Hakim [76] coined as the "grateful slaves" paradox. Albeit, past research suggests that men and women are increasingly similar in terms of job and life satisfaction [77]. Altogether, Hypothesis 5 states that different job satisfaction latent mean levels are observed, among different countries (Hypothesis 5.1) and different sexes (Hypothesis 5.2).

\section{Method}

\section{Sampling and data collection}

For this study, two samples of multi-occupational workers were collected $(N=1,171 ; \mathrm{S} 1$ and S2 Datasets). One sample is composed of Brazilian workers $(n=599)$ working in Brazil, and one other sample is composed of Portuguese workers $(n=572)$ working in Portugal. The sample from Portugal had an average age of $35.83(S D=9.76)$ with $37.16 \%$ being males, $83.07 \%$ had graduation or higher academic level, the occupational group with most participants was professionals (53.63\%). The sample from Brazil had an average age of $35.11(S D=10.13)$, with $32.77 \%$ of males, $74.39 \%$ had graduation or higher academic level, professionals were most represented occupational group (36.12\%).

The socioeconomic status according to the 2014 version of the Brazilian Criteria [78] was obtained, consisting of a socioeconomic classification of the households ranging from $\mathrm{A} 1$ (best socioeconomic level) to $\mathrm{E}$ (worst socioeconomic level) (Table 1). Additional variables regarding the characterization of the samples are available in Table 1.

A non-probabilistic convenience sample was collected within a cross-sectional survey through an online tool software [80]. The inclusion criteria were being workers with a contract or formal ties with their employers, literate, and with access to a device where the survey could be fulfilled.

\section{Constructs and measures}

Short Index of Job Satisfaction (SIJS). The Index of Job Satisfaction is a self-report psychometric instrument created by Brayfield and Rothe [28]. The original version was composed of 18 items, although a shorter version with five items (SIJS) has also been proposed [29,81]. Subjects are asked to respond to each item by checking a five-point scale ( 1 -"Strongly Disagree", 2 -"Disagree", 3 -"Undecided", 4 -“Agree", 5 -"Strongly Agree") two of those items are reversed (Table 2). Regarding the validity evidence based on the internal structure in terms of reliability, this shorter five items version presented a good internal consistency evidence ( $\alpha$ $=.89)$ [29]. Similar evidence was found in another study $(\alpha=.82$ to .83$)$ [82]. The ITC Guidelines for Translating and Adapting Tests were used to adapt the SIJS to Portuguese in a single version (using the Portuguese Language Orthographic Agreement of 1990) that could be used both for Portugal and Brazil with the same items [83]. The pilot data on the SIJS adapted version to the Portuguese language used 15 workers from Brazil and 15 workers from Portugal.

Quality of Working Life Scale (QWLS). The Quality of Work Life (i.e. second-order factor) was measured with the QWLS in its Brazil and Portugal version [84]. This instrument has 
Table 1. Demographics, career, academic level and occupational group statistics across countries.

\begin{tabular}{|c|c|c|c|}
\hline & Portugal $(n=572)$ & Brazil $(n=572)$ & Comparisons \\
\hline \multicolumn{4}{|c|}{ Academic level \% } \\
\hline High school, vocational education or less & 12.26 & 12.52 & \multirow[t]{6}{*}{$\chi 2(4)=153.682 ; p<.001 ; V=.395$} \\
\hline Unfinished graduation & 4.67 & 13.09 & \\
\hline Graduation & 29.57 & 34.16 & \\
\hline Post-graduation (not master neither PhD) & 9.34 & 25.62 & \\
\hline Master & 38.52 & 9.49 & \\
\hline $\mathrm{PhD}$ & 5.64 & 5.12 & \\
\hline \multicolumn{4}{|c|}{ Demographics and career } \\
\hline Working years in the current job sector $M(S D)$ & $11.23(9.69)$ & $9.73(8.61)$ & $t(983.35)=-2.607 ; p=.009 ; d=.164$ \\
\hline Working years in the current organization $M(S D)$ & $8.11(8.92)$ & $5.84(6.80)$ & $t(924.95)=-4.544 ; p<.001 ; d=.287$ \\
\hline Working years in the current job $M(S D)$ & $6.14(7.05)$ & $4.97(6.29)$ & $t(986.08)=-2.760 ; p=.006 ; d=.174$ \\
\hline$\underline{\text { Sex (males) \% }}$ & 37.16 & 32.77 & $\chi 2(1)=2.024 ; p=.155 ; \varphi=.046$ \\
\hline Age $M(S D)$ & $35.83(9.76)$ & $35.11(10.13)$ & $t(1,039)=-1.169 ; p=.243 ; d=.072$ \\
\hline \multicolumn{4}{|c|}{ Occupational groups $* \%$} \\
\hline Elementary Occupations & 1.81 & 1.55 & \multirow[t]{10}{*}{$\chi 2(8)=81.394 ; p<.001 ; V=.284$} \\
\hline Plant and Machine Operators and Assemblers & 0.60 & 0.78 & \\
\hline Craft and Related Trades Workers & 2.22 & 2.14 & \\
\hline Skilled Agricultural, Forestry and Fishery Workers & - & - & \\
\hline Services and Sales Workers & 6.05 & 6.21 & \\
\hline Clerical Support Workers & 9.48 & 27.38 & \\
\hline Technicians and Associate Professionals & 12.90 & 8.74 & \\
\hline Professionals & 53.63 & 36.12 & \\
\hline Managers & 8.87 & 15.53 & \\
\hline Armed Forces Occupations & 4.44 & 1.55 & \\
\hline \multicolumn{4}{|c|}{ Socioeconomic status \% } \\
\hline A1 & 14.06 & 9.11 & \multirow[t]{8}{*}{$\chi 2(6)=38.045 ; p<.001 ; V=.191$} \\
\hline $\mathrm{A} 2$ & 54.69 & 45.16 & \\
\hline $\mathrm{B} 1$ & 25.20 & 29.60 & \\
\hline B2 & 4.69 & 10.06 & \\
\hline $\mathrm{C} 1$ & 1.17 & 5.31 & \\
\hline $\mathrm{C} 2$ & 0.20 & 0.38 & \\
\hline $\mathrm{D}$ & - & 0.38 & \\
\hline $\mathrm{E}$ & - & - & \\
\hline
\end{tabular}

https://doi.org/10.1371/journal.pone.0231474.t001

16 items that are answered with a seven-point scale (Likert-type; from 1- "Very Untrue" to 7 -"Very True").

This measure comprises a second-order factor-Quality of Work Life-and seven first-order factors (i.e. seven major needs) which are: (1) economic and family needs;(2) health and safety needs; (3) aesthetic needs; (4) actualization needs; (5) esteem needs; (6) knowledge needs; and (7) social needs [12]. This measure tries to assess the workers' perception of how the job requirements, work environment, support programs, and supervisor behavior meet their needs. In its Portuguese version for Portugal and Brazil, it has shown good psychometric properties (measurement invariance across Portugal and Brazil, and genders) [84]. It also revealed good second-order internal consistency values both for Brazil $\left(\omega_{L 2}=.96 ; \omega_{L 1}=.90 ; \omega_{\text {partial } L 1}=\right.$ $.94)$ and Portugal $\left(\omega_{L 2}=.95 ; \omega_{L 1}=.88 ; \omega_{\text {partial } L 1}=.93\right)$. 
Table 2. SIJS original and Portuguese versions.

\begin{tabular}{|c|c|c|c|c|c|c|c|c|c|c|}
\hline \multirow[t]{3}{*}{ Item } & \multicolumn{5}{|c|}{ Original SIJS [29] } & \multicolumn{5}{|c|}{ Portuguese (Brazil and Portugal) version of SIJS } \\
\hline & Strongly Disagree & Disagree & Undecided & Agree & Strongly Agree & Discordo Fortemente & Discordo & Indeciso & Concordo & Concordo Fortemente \\
\hline & 1 & 2 & 3 & 4 & 5 & 1 & 2 & 3 & 4 & 5 \\
\hline 1 & \multicolumn{5}{|c|}{ I feel fairly satisfied with my present job } & \multicolumn{5}{|c|}{ Sinto-me razoavelmente satisfeito com meu emprego atual } \\
\hline 2 & \multicolumn{5}{|c|}{ Most days I am enthusiastic about my work } & \multicolumn{5}{|c|}{ Na maioria dos dias, estou entusiasmado com o meu trabalho } \\
\hline $3^{\mathrm{R}}$ & \multicolumn{5}{|c|}{ Each day at work seems like it will never end (R) } & \multicolumn{5}{|c|}{ Cada dia no trabalho parece não ter fim (R) } \\
\hline 4 & \multicolumn{5}{|c|}{ I find real enjoyment in my work } & \multicolumn{5}{|c|}{ Sinto-me realmente satisfeito no meu trabalho } \\
\hline $5^{\mathrm{R}}$ & \multicolumn{5}{|c|}{ I consider my job to be rather unpleasant (R) } & \multicolumn{5}{|c|}{ Considero que meu emprego é particularmente desagradável (R) } \\
\hline
\end{tabular}

${ }^{\mathrm{R}}$ Reversed items.

Oldenburg Burnout Inventory (OLBI). The Oldenburg Burnout Inventory (OLBI) in its version for Portugal and Brazil [57] was used to measure burnout. Burnout is an occupational phenomenon; a workplace syndrome that results from coping unsuccessfully with chronic stressors from the occupational context [85]. This instrument assumes a second-order latent factor-Burnout-that comprises two first-order factors, Exhaustion (eight items) and Disengagement (seven items) which are rated from $5=$ "Strongly Agree" to $1=$ "Strongly Disagree". Disengagement refers to a distancing and gradual loss of concern with one’s work recipients or contents, while exhaustion refers to a state of draining energy as a result of cognitive, emotional and physical strain [86]. The selected OLBI's version presented good validity evidence base in the internal structure (i.e. dimensionality, reliability of the scores in terms of second-order internal consistency values $\left[\omega_{L 2}=.91 ; \omega_{L 1}=.86 ; \omega_{\text {partial L1 }}=.93\right]$, and measurement invariance among countries and sexes) and based on the relation to other variables (i.e. nomological; discriminant evidence with work engagement).

Utrecht Work Engagement Scale (UWES). Work engagement was measured using the Utrecht Work Engagement Scale (short-version; nine items) in its Portuguese version for Portugal and Brazil [56]. It measures work engagement as a second-order latent factor which can be defined as a fulfilling, and positive state of mind related to work, with three (first-order) dimensions: absorption, dedication, and vigor [87]. Absorption is defined as one feeling totally concentrated and happily immersed at work [88]. Dedication refers to a sense of significance, challenge inspiration, pride and enthusiasm [87]. Vigor is defined as having high levels of energy [88]. As such, each of these three dimensions has three items, which are answered using a seven-point scale, from $0=$ "Never" to $6=$ "Always". This instrument has presented good validity evidence with Portuguese samples [89,90], namely in terms of dimensionality, measurement invariance (among Brazil and Portugal), reliability (second-order internal consistency values $\left.\left[\omega_{L 2}=.96 ; \omega_{L 1}=.93 ; \omega_{\text {partial } L 1}=.97\right]\right)$ and expected relation to other variables [56].

\section{Procedure}

The participants from both countries were invited to answer the selected instruments, sociodemographic and career questions. They were contacted individually or through companies that accepted to share the study by email. The cross-sectional data (i.e. cross-sectional survey) was collected using the LimeSurvey software [80] through the website of two major universities one in each of the two countries. The participation rate of the subjects that clicked in the invitation link from Brazil was $68.07 \%$ while $74.38 \%$ of Portuguese sample that clicked on the link fulfilled the survey. The participants were presented with the electronic informed consent in the first place, and after accepting it, had access to the survey per se. This study was approved by 
the Committee of Ethics in Research with Human Beings (CEP) of the Faculty of Philosophy, Sciences, and Letters of Ribeirão Preto, University of São Paulo, through "platform Brazil" of CONEP (National Commission of Ethics in Research). The written consent was obtained with the approval number 33301214.2.0000.5407. This study was also approved by the Ethics Committee of the Faculty of Psychology and Education Sciences of the University of Porto, the written consent had the following statement "the Ethics Committee of the Faculty of Psychology and Education Sciences of the University of Porto, having analyzed the research project ... considers that it respects all ethical principles and ethical standards of research and therefore gives a favorable opinion".

\section{Data analysis}

The statistical program $R$ [91] through the integrated development RStudio [92] was used to perform all statistical analyses. The skimr package [93] produced descriptive statistics. The multivariate normality was verified by the multivariate kurtosis [94] which was obtained using the psych package [95].

The confirmatory factor analysis (CFA) was the statistical technique selected to test the dimensionality of the instrument model. The lavaan package [96] was used to perform CFAs and multigroup CFA (MGCFA) with the Weighted Least Squares Means and Variances (WLSMV) estimator [97]. Some goodness-of-fit indices were selected: $\chi^{2}$ (chi-square), RMSEA (Root Mean Square Error of Approximation), SRMR (Standardized Root Mean Square Residual), CFI (Comparative Fit Index), NFI (Normed Fit Index), and the TLI (Tucker Lewis Index). Regarding the CFI, NFI, and TLI, Hu and Bentler [98] recommended that values above .95 should be considered as indicative of good fit. The RMSEA and SRMR values below .08 should be considered as good $[99,100]$. Model modifications were added through the analysis of the modification indices $(>30 ; p<.001)$ together with theoretical considerations.

The convergent evidence (in terms of internal structure) was assessed through the Average Variance Extracted [AVE; 101] calculated from polychoric correlations [102] where AVE $\geq$ .50 was considered as adequate convergent validity evidence [100].

The reliability of the scores evidence in terms of internal consistency was approached with the ordinal $\alpha$ [103], Composite Reliability [CR; 101] and $\omega[104,105]$ coefficients. The ordinal $\alpha$ coefficient was calculated from the polychoric correlations matrix. For the three coefficients, values $\geq .70$ were considered as indicative of acceptable reliability of the scores [100]. In the case of the second-order latent factors, three reliability estimates were calculated: the variance of the first-order factors explained by the second-order factor $\left(\omega_{L 2}\right)$, the proportion of the second-order factor explaining the total score $\left(\omega_{L 1}\right)$, and the proportion of variance explained by second-order factor after partialling the uniqueness of the first-order factor $\left(\omega_{\text {partialLI } 1}\right)$. Both the $\omega$ (both for first- and second-order factors) and the $\alpha$ coefficients were calculated using the semTools package [102].

The measurement invariance of the SIJS was evaluated through multigroup confirmatory factor analysis (MGCFA) which-considering the categorical nature of items-was analyzed using the theta-parameterization [106]. Five nested models were compared to test configural invariance, metric invariance, scalar invariance, strict invariance and homogeneity of factor means. For such analysis the semTools package [102] was used. The full structural equation models were analyzed through the lavaan package [96].

Using the structural equation modeling framework, the latent variables mean scores were compared using as effect size the Cohen's $d$ [107]. Additionally, for the job satisfaction raw scores the means, standard deviations and quartiles were calculated through the doBy package [108]. Regarding the demographics, career, academic level and occupational group variables, 
the frequencies were compared using the chi-square test using the Cramér's V [109] or the $\varphi$ [110] as an effect size measure using the $l s r$ package [111] and the psych package [95] respectively. The factor means were compared using the independent two-sample $t$-test or the Welch's $t$-test when the variances were not equal. Cohen's $d$ [107] was used as estimator of effect size obtained through the lsr package [111].

\section{Results}

\section{Validity evidence based on the internal structure}

Dimensionality. Items' distributional properties. The SIJS' items were analyzed in terms of its descriptive statistics (Table 3) which did not reveal severe violations in terms of univariate normality, since none of the items (for both samples) presented absolute values of Sk above 3 or absolute values of Ku above 7 [112]. In terms of multivariate normality, both samples had values of Mardia's multivariate kurtosis indicative of the absence of multivariate normality: Portugal $(27.61, p<.001)$ and Brazil $(16.10, p<.001)$. The maximum possible range of answers was observed in the five items and there was no outliers deletion. Altogether the distributional proprieties of the items indicate adequate psychometric sensitivity, however failing to achieve multivariate normality. As such, the WLSMV estimator that does not assume multivariate normality was used being also more adequate to the ordinal nature of the SIJS items.

Factor related validity evidence. The factorial validity evidence of the original proposed single latent factor was acceptable for the joint sample (Fig $1 ; \chi^{2}(5)=108.469 ; p<.001 ; n=1,171$; $C F I=.994 ; N F I=.993 ; T L I=.987 ; S R M R=.055 ; R M S E A=.133 ; P($ rmsea $) \leq .05)<.001 ; 90 \%$ CI ].112; .155[). Although, after checking the modification indices it was noticed that the correlation path between the residuals of the items 3 and 5 could improve the model's fit. That correlation was added $(r=.322 ; p<.001)$ and the fit to the data was very good $\left(\chi^{2}(4)=11.228\right.$; $p=.024 ; n=1,171 ; C F I=1.000 ; N F I=.999 ; T L I=.999 ; S R M R=.021 ; R M S E A=.039 ; P($ rmsea $)$ $\leq .05)=.698 ; 90 \% \mathrm{CI}] .013 ; .067[$ ). All factor loadings $(\lambda)$ and the items 3 and 5 residuals' correlation were statistically significant. There were no items removed. The minimum item loading for the SIJS was .57. The fit of the data to the model with one correlation between the referred items in the Brazilian sample was good $\left(\chi^{2}(4)=11.486 ; p=.022 ; n=599 ; C F I=.999\right.$; $N F I=.998 ; T L I=.997 ; S R M R=.030 ; R M S E A=.056 ; P(\mathrm{rmsea}) \leq .05)=.339 ; 90 \% \mathrm{CI}] .019$; .095 [) the same was observed in the Portuguese data $\left(\chi^{2}(4)=6.726 ; p<.001 ; n=572\right.$;

Table 3. Sample 1 and 2 descriptive statistics.

\begin{tabular}{|c|c|c|c|c|c|c|c|c|c|c|}
\hline Item & $M$ & $S D$ & Min & Q1 & $M d n$ & Q3 & $\operatorname{Max}$ & Histogram & $S k$ & $K u$ \\
\hline \multicolumn{11}{|c|}{ Brazil } \\
\hline Item 1 -“fairly satisfied" & 3.41 & 1.27 & 1 & 3 & 4 & 4 & 5 & & -0.46 & -0.77 \\
\hline Item 2 -"enthusiastic" & 3.49 & 1.19 & 1 & 3 & 4 & 4 & 5 & & -0.43 & -0.74 \\
\hline Item $3^{\mathrm{R}}$-"it will never end" & 3.54 & 1.25 & 1 & 3 & 4 & 5 & 5 & & -0.58 & -0.66 \\
\hline Item 4 -"real enjoyment" & 3.40 & 1.23 & 1 & 3 & 4 & 4 & 5 & & -0.43 & -0.77 \\
\hline Item $5^{\mathrm{R}}$-"unpleasant" & 4.15 & 1.12 & 1 & 3 & 5 & 5 & 5 & & -1.13 & 0.28 \\
\hline \multicolumn{11}{|c|}{ Portugal } \\
\hline Item 1 -"fairly satisfied" & 3.48 & 1.11 & 1 & 3 & 4 & 4 & 5 & & -0.49 & -0.42 \\
\hline Item 2 -"enthusiastic" & 3.51 & 1.13 & 1 & 3 & 4 & 4 & 5 & & -0.56 & -0.38 \\
\hline Item $3^{\mathrm{R}}$-"it will never end" & 3.68 & 1.13 & 1 & 3 & 4 & 5 & 5 & & -0.60 & -0.42 \\
\hline Item 4 -"real enjoyment" & 3.31 & 1.16 & 1 & 3 & 3 & 4 & 5 & & -0.40 & -0.64 \\
\hline Item $5^{\mathrm{R}}$-"unpleasant" & 4.30 & 1.01 & 1 & 4 & 5 & 5 & 5 & & -1.45 & 1.51 \\
\hline
\end{tabular}

${ }^{\mathrm{R}}$ Reversed items; the descriptive statistics of such items refer to the recoded scores.

https://doi.org/10.1371/journal.pone.0231474.t003 
$C F I=1.000 ; N F I=1.000 ; T L I=1.000 ; S R M R=.019 ; R M S E A=.035 ; P($ rmsea $) \leq .05)=.661 ;$ $90 \%$ CI ].000;.078[).

Convergent validity evidence. The AVE value for the job satisfaction factor was .58, which is indicative of good convergent validity evidence for this factor. Good AVE values were also observed for each country $\left(A V E_{\text {Brazil }}=.54 ; A V E_{\text {Portugal }}=.65\right)$. Globally, these results indicate good convergent validity evidence in terms of internal structure for SIJS. In other words, the items contained in the job satisfaction factor relate to each other.

\section{Reliability of the scores}

The reliability of the scores was assessed through internal consistency estimates which revealed to be globally very good values for both samples (Table 4). The values of the internal consistency estimates were very good $(\geq .84)$ for the Brazilian data, with the CR obtaining the highest value. In the case of the Portuguese sample all internal consistency estimates were also very good $(\geq .88)$. Such results are indicative of very good evidence in terms of reliability, suggesting that items' scores are homogenously crowded together around the job satisfaction latent variable.

\section{Measurement invariance}

The measurement invariance among countries and sexes was tested through a group of nested models with increasing constraints (Table 5). Scalar invariance was achieved among countries considering the $\Delta C F I<.010$ criterion [113] while using the $\Delta \chi^{2}$ criterion [114] only metric invariance was achieved. Regarding the measurement invariance among sexes in the Brazilian sample, full uniqueness measurement invariance was obtained using the $\Delta C F I<.010$ criterion, while the $\Delta \chi^{2}$ criterion only supported metric invariance. The Portuguese sample showed that full uniqueness measurement invariance was supported by both criteria (i.e. $\Delta C F I<.010$ and $\left.\Delta \chi^{2}\right)$. That is to say that the SIJS measures job satisfaction in the same way across countries and sexes, allowing to interpret the differences in terms of group differences in the job satisfaction construct.

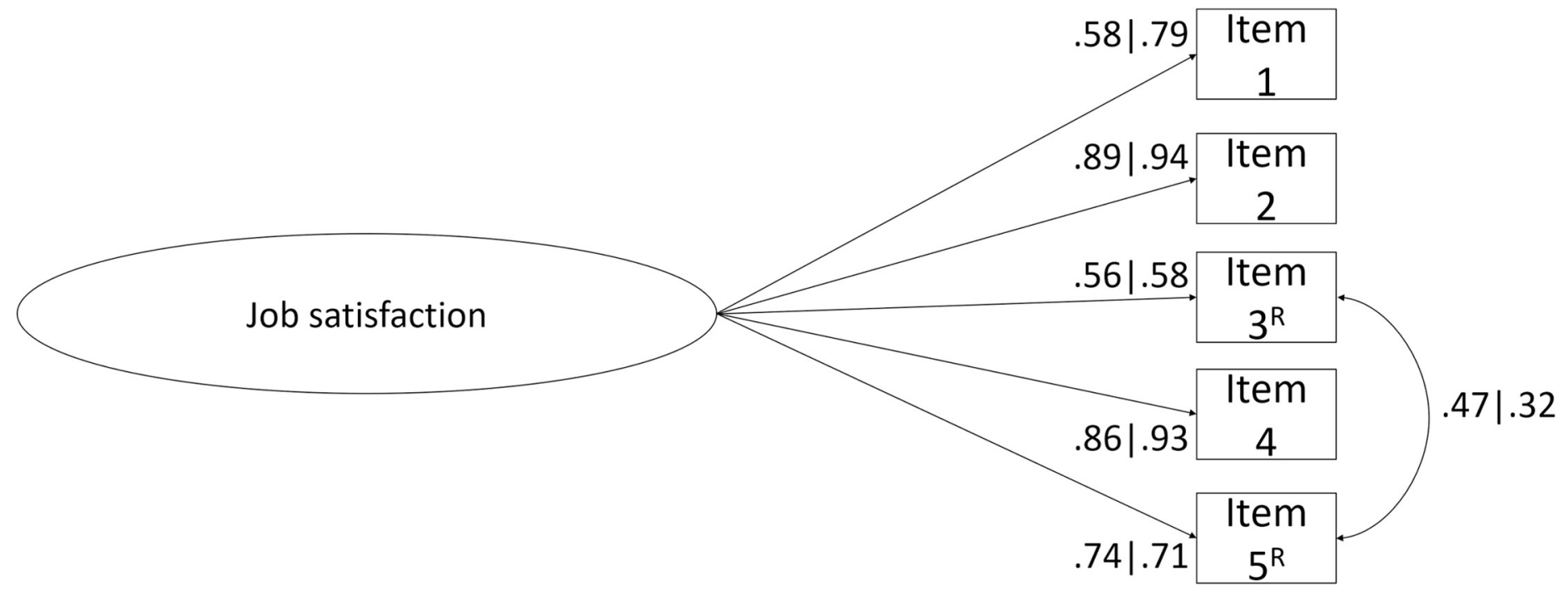

Fig 1. SIJS latent structure (five items). Factor loadings for each item are shown (Brazil | Portugal). ${ }^{\mathrm{R}}$ Reversed items. 
Table 4. Internal consistency estimates for both samples.

\begin{tabular}{|c|c|c|c|c|c|c|c|c|c|}
\hline \multirow[t]{3}{*}{ SIJS dimension } & \multicolumn{9}{|c|}{ SIJS-5 items } \\
\hline & \multicolumn{3}{|c|}{ Brazil } & \multicolumn{3}{|c|}{ Portugal } & \multicolumn{3}{|c|}{ Total } \\
\hline & $\alpha$ & $\omega$ & $C R$ & $\alpha$ & $\omega$ & $C R$ & $\alpha$ & $\omega$ & $C R$ \\
\hline Job Satisfaction & .86 & .84 & .87 & .90 & .88 & .90 & .88 & .86 & .88 \\
\hline
\end{tabular}

\section{Validity evidence based on relations to other variables}

Three additional measures were used to investigate the validity evidence based on relations to other variables, particularly the nomological validity both in terms of convergent and discriminant evidence [49]. Using the OLBI second-order factor model which revealed an acceptable fit to the data $\left(\chi^{2}(86)=1,039.970 ; p<.001 ; n=1,109 ; C F I=.984 ; N F I=.983 ; T L I=.981\right.$; $S R M R=.065 ; R M S E A=.100 ; P($ rmsea $) \leq .05)<.001 ; 90 \%$ CI $] .095 ; .106[)$ after adding three pairs of correlations between items' residuals (i.e. Item $1_{\mathrm{OLBI}}$-Item $7_{\mathrm{OLBI}}$; Item $10_{\mathrm{OLBI}}-$ Item $12_{O L B I}$; and Item $4_{O L B I}-$ Item $\left.16_{O L B I}\right)$. Such correlations were added after the analysis of modification indices because the items in each pair belong to the same factor. Since it seems plausible that residuals of the same factor are correlated [115]. The UWES-9 second-order model also obtained an acceptable fit $\left(\chi^{2}(25)=437.948 ; p<.001 ; n=1,100 ; C F I=.998 ; N F I=\right.$ $.998 ; T L I=.997 ; S R M R=.041 ; R M S E A=.123 ; P($ rmsea $) \leq .05)<.001 ; 90 \%$ CI $] .113 ; .133[)$ after adding a constraint to the variance of one of the first-order factors-Dedication-fixing it to 0.001 to avoid negative variance. The QWLS-16 presented good fit $\left(\chi^{2}(97)=931.475 ; p<\right.$ $.001 ; n=1,108 ; C F I=.991 ; N F I=.990 ; T L I=.988 ; S R M R=.064 ; R M S E A=.088 ; P(\mathrm{rmsea}) \leq$ $.05)<.001 ; 90 \%$ CI ].083; .093[). Both in terms of first- and second-order factors the reliability

Table 5. Measurement invariance between countries.

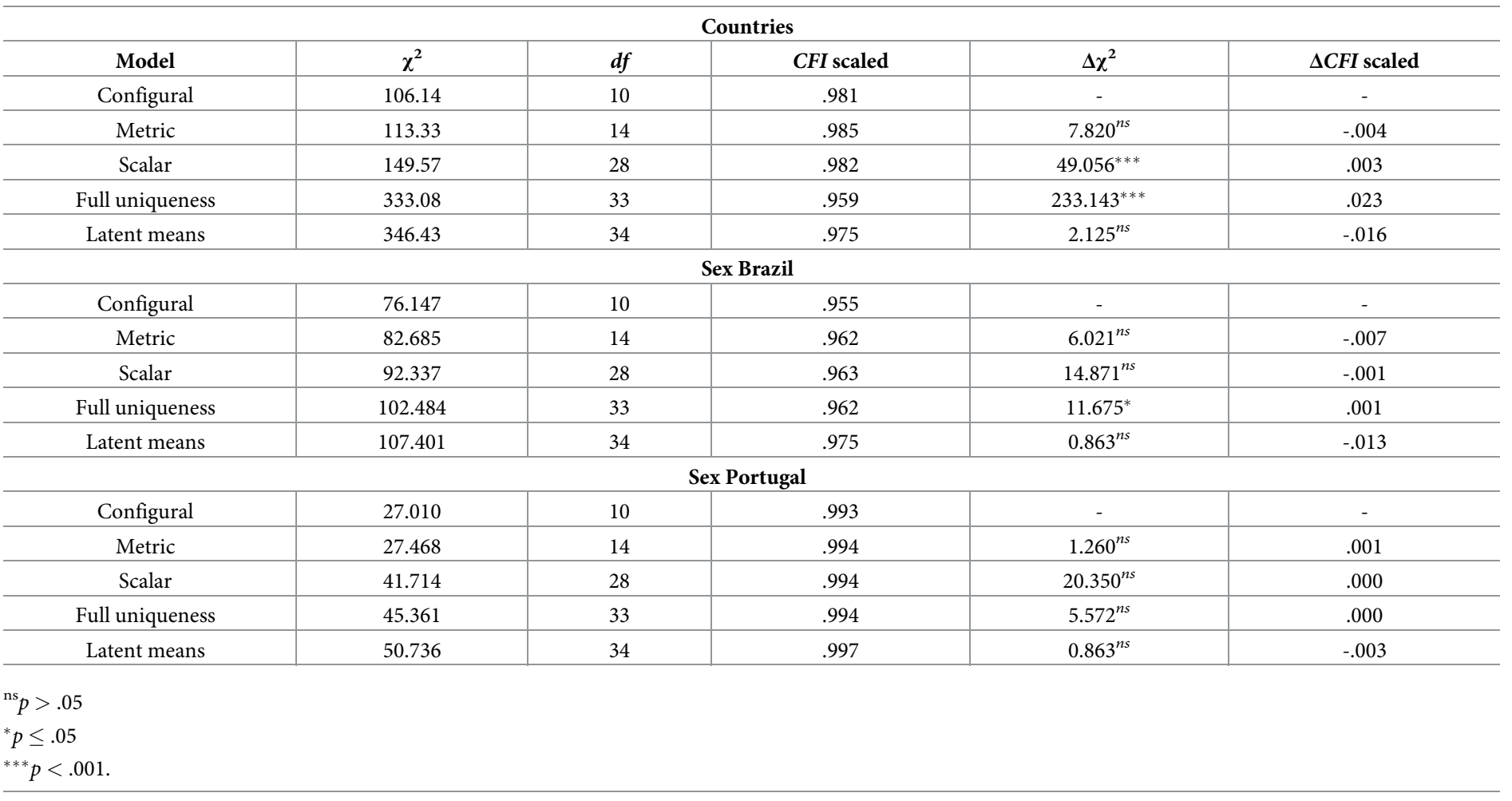

https://doi.org/10.1371/journal.pone.0231474.t005 
of the scores in terms of internal consistency for QWLS, UWES-9 and OLBI presented acceptable to very good evidence (Table 6).

In nomological terms, the convergent evidence was good, since both the model of quality of work life correlating with job satisfaction $\left(\chi^{2}(180)=1,126.605 ; p<.001 ; n=1,108 ; C F I=.993\right.$; $N F I=.992 ; T L I=.992 ; S R M R=.054 ; R M S E A=.069 ; P($ rmsea $) \leq .05)<.001,90 \%$ CI $] .065$; .073[) and the model of work engagement correlating with job satisfaction $\left(\chi^{2}(73)=669.163 ; p\right.$ $<.001 ; n=1,100 ; C F I=.998 ; N F I=.997 ; T L I=.997 ; S R M R=.038 ; R M S E A=.086 ; P(\mathrm{rmsea}) \leq$ $.05)<.001,90 \% \mathrm{CI}] .080 ; .092[)$ presented significant and strong correlations $\left(r_{J S, Q W L}=0.82\right.$; $r_{J S, W E}=0.86$, respectively).

The model where job satisfaction was correlated with burnout showed good fit to the data $\left(\chi^{2}(165)=1,558.286 ; p<.001 ; n=1,109 ; C F I=.988 ; N F I=.987 ; T L I=.986 ; S R M R=.061 ;\right.$ $R M S E A=.087 ; P(\mathrm{rmsea}) \leq .05)<.001,90 \% \mathrm{CI}] .083 ; .091[)$. The hypothetical model indicates a large and negative correlation between job satisfaction and burnout $\left(r_{J S, B}=-0.90 ; p<.001\right)$. Such result suggests good discriminant evidence in nomological terms. Altogether, the SIJS' validity evidence based on relations to other variables was satisfactory, showing associations in the expected directions in other associated measures.

\section{Job satisfaction comparisons among sex and country}

The job satisfaction latent means were compared through the structural equation modeling framework. The comparison among countries did not reveal statistically significant differences $\left(\Delta \chi_{\text {scaled }}^{2}(1)=2.125 ; p=0.145 ; d=0.086\right)$. Also, the comparison among sexes did not reveal statistically significant differences $\left(\Delta \chi_{\text {scaled }}^{2}(1)=0.126 p=0.723 ; d=-0.003\right)$. For potential comparison with other studies, job satisfaction means, standard deviations, and quartiles of the raw scores per country and sex are provided (Table 7).

\section{Discussion}

The SIJS presented a promising fit to data from multi-occupational workers from Portugal and Brazil. The minimum $\lambda$ value was high, and the instrument presented acceptable convergent validity evidence. Globally, the SIJS presented acceptable values of internal consistency, with scalar invariance obtained among the Portuguese and Brazilian samples and sexes. This is in line with the good psychometric properties observed in different countries such as the USA [82], Italy [116], New Zealand [47] or the UAE [52]. Due to its good validity evidence, the SIJS has been reported as a commonly used instrument of job satisfaction in studies published in top journals [117].

The dimensionality of the SIJS was successfully confirmed (H1), presenting an excellent fit to the data. However, a modification was added to the structure: the correlation among items' 3 and 5 residuals. Such correlation can be justified since both items belong to the same latent factor, and additionally both items are reversed. Interestingly, a study by Jabeen et al. [52] revealed problems with this pair of reversed items (i.e. unexpected factor loadings), which lead the authors to remove those items from the analysis. The discussion about the inclusion of reversed items reveals that there are specific trade-offs that researchers should be aware of [118-120].

The reliability evidence confirmed to be good (H2). Such findings are corroborated by other studies where the SIJS revealed adequate to good reliability evidence in terms of internal consistency [45-48]. Our study's internal consistency estimates values were good in the three different used estimates (i.e. $\alpha, \omega$ and CR).

Regarding Hypothesis 3, it was also confirmed. A minimum of scalar invariance was achieved both for countries and sexes. As far as we know, none of the other studies that used 
Table 6. UWES-9, OLBI, and QLWS internal consistency estimates.

\begin{tabular}{|c|c|c|c|}
\hline \multicolumn{4}{|c|}{ Internal consistency estimates } \\
\hline Estimate & UWES-9 ${ }^{2 L}$ & OLBI $^{2 L}$ & QWLS $^{2 L}$ \\
\hline \multirow[t]{7}{*}{$\omega$} & \multirow{2}{*}{ Vigor $=.94$} & \multirow[t]{4}{*}{ Disengagement $=.68$} & Health $\&$ Safety $=.43$ \\
\hline & & & Economic \& Family $=.64$ \\
\hline & \multirow[t]{3}{*}{ Dedication $=.91$} & & Social $=.46$ \\
\hline & & & Esteem $=.77$ \\
\hline & & \multirow[t]{3}{*}{ Exhaustion $=.86$} & Actualization $=.91$ \\
\hline & \multirow[t]{2}{*}{ Absorption $=.88$} & & Knowledge $=.90$ \\
\hline & & & Aesthetics $=.83$ \\
\hline$\omega_{\text {partial L1 }}$ & .97 & .93 & .96 \\
\hline$\omega_{L 1}$ & .93 & .86 & .92 \\
\hline$\omega_{L 2}$ & .96 & .92 & .96 \\
\hline
\end{tabular}

${ }^{2 L}$ Second-order latent version.

https://doi.org/10.1371/journal.pone.0231474.t006

the SIJS tested the measurement invariance of this instrument. As such, this finding is an interesting contribution to the literature. Strong measurement (scalar) invariance is an essential condition to directly compare an instrument score among groups [121].

The validity evidence based on the relation to other variables revealed to be satisfactory, since the tested full structural equation models presented paths that occurred as expected, confirming Hypothesis 4. More specifically, job satisfaction was associated with burnout (H4.1). The burnout association with overall job satisfaction is well known, albeit some argue that they can have bidirectional relations [122]. Others [e.g., 123] reported a strong negative correlation between emotional exhaustion (burnout's core dimension) and job satisfaction. Emotional exhaustion has been also observed to explain specific types of job satisfaction (e.g. satisfaction with the communication) [124].

Job satisfaction also correlated with work engagement (H4.2) a finding that has parallel in other studies $[125,126]$. Conversely in other studies, some authors tested work engagement as a predictor of job satisfaction, finding also a positive relationship between both variables [127,128].

The relation with quality of work-life was successfully verified (H4.3) similarly to previous research which showed that quality of work-life predicts job satisfaction [12,52]. The correlation magnitude is large which is somehow expected, since the used quality of work-life measure approaches the perception of needs satisfaction related to the supervisory behavior, job requirements, and work environment which-when occurs-conducts to job satisfaction [12].

Table 7. Job satisfaction raw scores: Quartiles, means, and standard deviations for countries and sexes.

\begin{tabular}{|c|c|c|c|c|c|c|c|c|c|c|c|c|c|c|}
\hline \multicolumn{15}{|c|}{ Brazil } \\
\hline \multicolumn{5}{|c|}{ Female $(n=355)$} & \multicolumn{5}{|c|}{ Male $(n=173)$} & \multicolumn{5}{|c|}{ Total $(n=599)^{*}$} \\
\hline$M$ & $S D$ & $P_{25}$ & $P_{50}$ & $P_{75}$ & $M$ & $S D$ & $P_{25}$ & $P_{50}$ & $P_{75}$ & $M$ & $S D$ & $P_{25}$ & $P_{50}$ & $P_{75}$ \\
\hline 3.58 & 0.95 & 3.00 & 3.80 & 4.20 & 3.68 & 0.87 & 3.00 & 3.80 & 4.20 & 3.60 & 0.92 & 3.00 & 3.80 & 4.20 \\
\hline \multicolumn{15}{|c|}{ Portugal } \\
\hline \multicolumn{5}{|c|}{ Female $(n=323)$} & \multicolumn{5}{|c|}{ Male $(n=191)$} & \multicolumn{5}{|c|}{ Total $(n=572)^{*}$} \\
\hline 3.68 & 0.91 & 3.20 & 3.80 & 4.40 & 3.61 & 0.89 & 3.00 & 3.80 & 4.20 & 3.66 & 0.90 & 3.00 & 3.80 & 4.40 \\
\hline
\end{tabular}

*Some subjects did not inform their Sex.

https://doi.org/10.1371/journal.pone.0231474.t007 
Portugal and Brazil did not present statistically significant differences regarding job satisfaction (H5.1). Since the sample was mainly constituted by workers with higher education, such finding was plausible. Others [e.g., 129], found that job satisfaction was rather similar across various countries among the higher education graduates. Countries with different cultural backgrounds can display different perceptions of job satisfaction, and such potential differences should be controlled before making comparisons [130]. Something that-regarding the Brazil and Portugal comparison-was guaranteed both by the procedure of adaptation of the items which considered both countries' cultural specificities and through the verification of the scalar invariance of the SIJS. Only after such evidence, direct comparisons of the scores can be established [131].

The hypothesis tested in H5.2 was not supported by the data. In Brazil, a previous study among health-care workers did not find statistically significant differences among genders [132]. In Portugal there are mixed findings, with some studies not finding statistically significant differences among men and women $[133,134]$ while others reported that men had higher job satisfaction than women[135]. Past studies in other countries found differences between sexes both with males having greater job satisfaction after controlling for similar job ranks [136], or the reverse effect [137], or even the absence of differences between women and men $[138,139]$. Kaiser [135] found that job satisfaction differences among sexes are expected to be insignificant within a higher job status segment. This seems a plausible explanation since the collected samples in the present paper have high frequencies of higher academic levels, which are expected to be associated with higher job status. Zou [140] reported that when work orientations are taken into account, job satisfaction differences among women and men are eliminated. Also, there is evidence that women and men are similar in the crossover and spillover dynamics regarding job satisfaction, job insecurity, own family and partner's family life satisfaction [141]. Various explanations exist for such absence, or even the possible greater job satisfaction perceived by women [142] which would be seen as a job satisfaction paradox [135]. Nulling effect of covariate variables of sex, like education, age and paygrade can explain the absence of differences [143].. perhaps due to the evolution of the demographics and women's attitudes towards work [77]. Such findings can be also explained by the less apparent differences among sexes in terms of job roles, qualifications, earnings and other indicators $[144,145]$. Such a fading-out process might be explained by appropriate labor market interventions by the governing institutions [135]. Hodson [142] suggested that women can report equal or greater job satisfaction than men, despite women's worst job conditions because of two possible processes that may operate in conjunction. First, women can use different comparison groups. Second, men can be more inclined to report situations of dissatisfaction than women.

\section{Conclusions}

The short measure (i.e. SIJS) can be taken as a good measure, since it has been used successfully in several studies [e.g. 6], and it also demonstrated promising validity in this study. Despite being shorter than several other instruments versions that measure job satisfaction [146] the SIJS revealed very promising validity evidence, both based in the internal structure as also based on the relations to other variables. When a researcher wants to use several measures, the length of the selected instruments is a fundamental issue to avoid respondents' fatigue. As such, having short scales that show good validity evidence is crucial since lengthy surveys can lead to fatigue and consequently have increased insufficient effort responding [147,148].

Some limitations of the current study should be mentioned. The sample was a convenience sample (i.e. non-probabilistic). Desirably in future studies probability sampling techniques 
should be used. Additionally, the two current samples do not have the same proportions of occupational groups, sex and academic level in each country. And since, the conclusions regarding invariance should be analyzed with caution. In this cross-sectional study, no information can be extracted regarding the temporal stability of the SIJS structure. In future research, researchers might address this issue by testing longitudinal measurement invariance [149]. Research with other samples (i.e. more specific occupational groups) is expected to occur in future studies, as also in other countries/cultures, to approach the transcultural invariance robustness of the SIJS.

\section{Supporting information}

S1 Dataset. The dataset used.

(CSV)

S2 Dataset. The dataset codebook.

(CSV)

\section{Acknowledgments}

The authors would like to thank the Portuguese national occupational health program of the Directorate-General of Health (DGS). We thank Dr. Edwin A. Locke (Robert H. Smith School of Business [Emeritus], University of Maryland, College Park, MD, United States of America) for helpful comments.

\section{Author Contributions}

Conceptualization: Jorge Sinval, João Marôco.

Data curation: Jorge Sinval.

Formal analysis: Jorge Sinval.

Funding acquisition: João Marôco.

Investigation: Jorge Sinval.

Methodology: Jorge Sinval, João Marôco.

Project administration: Jorge Sinval.

Software: Jorge Sinval.

Supervision: João Marôco.

Visualization: Jorge Sinval.

Writing - original draft: Jorge Sinval.

Writing - review \& editing: Jorge Sinval, João Marôco.

\section{References}

1. Wright TA. The emergence of job satisfaction in organizational behavior: A historical overview of the dawn of job attitude research. J Manag Hist. 2006; 12: 262-277. https://doi.org/10.1108/ 17511340610670179

2. Spagnoli $P$, Caetano A, Santos SC. Satisfaction with job aspects: Do patterns change over time? J Bus Res. 2012; 65: 609-616. https://doi.org/10.1016/j.jbusres.2011.02.048

3. Hoppock R. Job satisfaction [Internet]. New York, NY, USA: Harper; 1935. Available: https://books. google.pt/books?id=ovFCAAAAIAAJ 
4. Hoppock R, Spiegler S. Job satisfaction: Researches of 1935-1937. Occup Vocat Guid J. 1938; 16: 636-643. https://doi.org/10.1002/j.2164-5892.1938.tb00348.x

5. Spector PE. Job satisfaction: Application, assessment, causes, and consequences [Internet]. Thousand Oaks, CA, USA: SAGE; 1997. https://doi.org/10.4135/9781452231549

6. Judge TA, Parker S, Colbert AE, Heller D, llies R. Job satisfaction: A cross-cultural review. In: Anderson N, Ones DS, Sinangil HK, Viswesvaran C, editors. Handbook of industrial, work and organizational psychology: Organizational psychology. London, UK: SAGE; 2001. pp. 25-52. https://doi.org/10. 4135/9781848608368.n3

7. Locke EA. The nature and causes of job satisfaction. In: Dunnette MD, editor. Handbook of industrial and organizational psychology. Chicago, IL, USA: Rand McNally; 1976. pp. 1297-1343.

8. Judge TA, Kammeyer-Mueller JD. Job attitudes. Annu Rev Psychol. 2012; 63: 341-367. https://doi. org/10.1146/annurev-psych-120710-100511 PMID: 22129457

9. Credé M. Attitudes: Satisfaction, commitment and involvement. In: Ones DS, Anderson N, Viswesvaran C, Sinangil HK, editors. The SAGE handbook of industrial, work and organizational psychology: Organizational psychology. 2nd ed. London, UK: SAGE; 2018. pp. 3-23. https://doi.org/10.4135/ 9781473914957.n2

10. Knox S, Irving JA. An interactive quality of work life model applied to organizational transition. J Nurs Adm. 1997; 27: 39-47. https://doi.org/10.1097/00005110-199701000-00009 PMID: 9006600

11. Chan KW, Wyatt TA. Quality of work life: A study of employees in Shanghai, China. Asia Pacific Bus Rev. 2007; 13: 501-517. https://doi.org/10.1080/13602380701250681

12. Sirgy MJ, Efraty $D$, Siegel $P$, Lee $D-J$. A new measure of quality of work life (QWL) based on need satisfaction and spillover theories. Soc Indic Res. 2001; 55: 241-302. https://doi.org/10.1023/ A:1010986923468

13. Li A, Early SF, Mahrer NE, Klaristenfel JL, Gold Jl. Group cohesion and organizational commitment: Protective factors for nurse residents' job satisfaction, compassion fatigue, compassion satisfaction, and burnout. J Prof Nurs. 2014; 30: 89-99. https://doi.org/10.1016/j.profnurs.2013.04.004 PMID: 24503320

14. van Saane N, Sluiter JK, Verbeek JHAM, Frings-Dresen MHW. Reliability and validity of instruments measuring job satisfaction-A systematic review. Occup Med (Chic III). 2003; 53: 191-200. https://doi. org/10.1093/occmed/kgg038 PMID: 12724553

15. Bhave DP, Glomb TM. The role of occupational emotional labor requirements on the surface actingjob satisfaction relationship. J Manage. 2016; 42: 722-741. https://doi.org/10.1177/ 0149206313498900

16. Dobrow Riza S, Ganzach Y, Liu Y. Time and job satisfaction: A longitudinal study of the differential roles of age and tenure. J Manage. 2018; 44: 2558-2579. https://doi.org/10.1177/0149206315624962

17. Irvine DM, Evans MG. Job satisfaction and turnover among nurses. Nurs Res. 1995; 44: 246-253. https://doi.org/10.1097/00006199-199507000-00010 PMID: 7624236

18. Lance CE. Evaluation of a structural model relating job satisfaction, organizational commitment, and precursors to voluntary turnover. Multivariate Behav Res. 1991; 26: 137-162. https://doi.org/10.1207/ s15327906mbr2601_7 PMID: 26782615

19. Zito M, Emanuel F, Molino M, Cortese CG, Ghislieri C, Colombo L. Turnover intentions in a call center: The role of emotional dissonance, job resources, and job satisfaction. Georgantzis N, editor. PLoS One. 2018; 13: 1-16. https://doi.org/10.1371/journal.pone.0192126 PMID: 29401507

20. Judge TA, llies R. Affect and job satisfaction: A study of their relationship at work and at home. J Appl Psychol. 2004; 89: 661-673. https://doi.org/10.1037/0021-9010.89.4.661 PMID: 15327352

21. Burton WN, Chen C-Y, Conti DJ, Schultz AB, Pransky G, Edington DW. The association of health risks with on-the-job productivity. J Occup Environ Med. 2005; 47: 769-777. https://doi.org/10.1097/ 01.jom.0000169088.03301.e4 PMID: 16093926

22. Rantanen I, Tuominen R. Relative magnitude of presenteeism and absenteeism and work-related factors affecting them among health care professionals. Int Arch Occup Environ Health. 2011; 84: 225230. https://doi.org/10.1007/s00420-010-0604-5 PMID: 21140162

23. Caverley N, Cunningham JB, MacGregor JN. Sickness presenteeism, sickness absenteeism, and health following restructuring in a public service organization. J Manag Stud. 2007; 44: 304-319. https://doi.org/10.1111/j.1467-6486.2007.00690.x

24. Bakotić D. Relationship between job satisfaction and organisational performance. Econ Res Istraživanja. 2016; 29: 118-130. https://doi.org/10.1080/1331677X.2016.1163946

25. Weiss HM, Cropanzano R. Affective events theory: A theoretical discussion of the structure, causes and consequences of affective experiences at work. Staw BM, Cummings LL, editors. Research in 
organizational behavior: An annual series of analytical essays and critical reviews. Greenwich, CT, USA: JAI Press; 1996.

26. Judge TA, Hulin CL, Dalal RS. Job satisfaction and job affect. In: Kozlowski SWJ, editor. The Oxford handbook of organizational psychology. Oxford University Press; 2012. pp. 496-525. https://doi.org/ 10.1093/oxfordhb/9780199928309.013.0015

27. Wanous JP, Reichers AE, Hudy MJ. Overall job satisfaction: How good are single-item measures? J Appl Psychol. 1997; 82: 247-252. https://doi.org/10.1037/0021-9010.82.2.247 PMID: 9109282

28. Brayfield AH, Rothe HF. An index of job satisfaction. J Appl Psychol. 1951; 35: 307-311. https://doi. org/10.1037/h0055617

29. Judge TA, Bono JE, Locke EA. Personality and job satisfaction: The mediating role of job characteristics. J Appl Psychol. 2000; 85: 237-249. https://doi.org/10.1037/0021-9010.85.2.237 PMID: 10783540

30. Traynor $\mathrm{M}$, Wade $\mathrm{B}$. The development of a measure of job satisfaction for use in monitoring the morale of community nurses in four trusts. J Adv Nurs. 1993; 18: 127-136. https://doi.org/10.1046/j.13652648.1993.18010127.x PMID: 8429157

31. Ironson GH, Smith PC, Brannick MT, Gibson WM, Paul KB. Construction of a Job in General scale: A comparison of global, composite, and specific measures. J Appl Psychol. 1989; 74: 193-200. https:// doi.org/10.1037/0021-9010.74.2.193

32. Smith PC, Kendall LM, Hulin CL. The measurement of satisfaction in work and retirement: A strategy for the study of attitudes. Oxford, England: Rand Mcnally; 1969.

33. Andrews FM, Withey SB. Social indicators of well-being: Americans' perceptions of life quality [Internet]. Boston, MA, USA: Springer; 1976. https://doi.org/10.1007/978-1-4684-2253-5

34. Spector PE. Measurement of human service staff satisfaction: Development of the Job Satisfaction Survey. Am J Community Psychol. 1985; 13: 693-713. https://doi.org/10.1007/bf00929796 PMID: 4083275

35. Weiss DJ, Dawis R, England GW, Lofquist LH. Manual for the Minnesota Satisfaction Questionnaire [Internet]. Minnesota Studies in Vocational Rehabilitation. Minneapolis,MN, USA: University of Minnesota; 1967. doi:Article

36. Cammann C, Fichman M, Jenkins GD, Klesh JR. Assessing the attitudes and perceptions of organizational members. In: Seashore SE, Lawler EE, Mirvis PH, Cammann C, editors. Assessing organizational change: A guide to methods, measures, and practices. New York, NY, USA: WileyInterscience; 1983. pp. 71-138.

37. Macdonald S, Maclntyre P. The Generic Job Satisfaction Scale: Scale development and its correlates. Empl Assist Q. 1997; 13: 1-16. https://doi.org/10.1300/J022v13n02_01

38. Hartley J, Jacobson D, Klandermans B, Van Vuuren T, editors. Job insecurity: Coping with jobs at risk [Internet]. London, UK: Sage Publications; 1991. Available: https://books.google.pt/books?id= CC7TAAAAMAAJ

39. Oshagbemi T. Overall job satisfaction: How good are single versus multiple-item measures? J Manag Psychol. 1999; 14: 388-403. https://doi.org/10.1108/02683949910277148

40. Nagy MS. Using a single-item approach to measure facet job satisfaction. J Occup Organ Psychol. 2002; 75: 77-86. https://doi.org/10.1348/096317902167658

41. Nunnally JC, Bernstein IH. Psychometric theory. 3rd ed. New York, NY, USA: McGraw-Hill; 1994.

42. Borsboom D, Mellenbergh GJ, van Heerden J. The theoretical status of latent variables. Psychol Rev. 2003; 110: 203-219. https://doi.org/10.1037/0033-295X.110.2.203 PMID: 12747522

43. Wanous JP, Reichers AE. Estimating the reliability of a single-item measure. Psychol Rep. 1996; 78: 631-634. https://doi.org/10.2466/pr0.1996.78.2.631

44. Heggestad ED, Scheaf DJ, Banks GC, Monroe Hausfeld M, Tonidandel S, Williams EB. Scale adaptation in organizational science research: A review and best-practice recommendations. J Manage. 2019; 45: 2596-2627. https://doi.org/10.1177/0149206319850280

45. Yücel I. Examining the Relationships among job satisfaction, organizational commitment, and turnover intention: An empirical study. Int J Bus Manag. 2012; 7: 44-58. https://doi.org/10.5539/ijbm.v7n20p44

46. Jawahar IM, Liu Y. Why are proactive people more satisfied with their job, career, and life? An examination of the role of work engagement. J Career Dev. 2017; 44: 344-358. https://doi.org/10.1177/ 0894845316656070

47. Ang HB (Andy), Woodside AG. Is Bart Simpson offering sage advice? A case-based general theory of managers' core self-evaluations and job satisfaction. J Bus Res. 2017; 74: 11-37. https://doi.org/10. 1016/j.jbusres.2017.01.005 
48. Judge TA, Locke EA, Durham CC, Kluger AN. Dispositional effects on job and life satisfaction: The role of core evaluations. J Appl Psychol. 1998; 83: 17-34. https://doi.org/10.1037/0021-9010.83.1.17 PMID: 9494439

49. American Educational Research Association, American Psychological Association, National Council on Measurement in Education. Standards for Educational and Psychological Testing. Washington, DC, USA: American Psychological Association; 2014.

50. Jawahar IM, Liu Y. Proactive personality and citizenship performance: The mediating role of career satisfaction and the moderating role of political skill. Career Dev Int. 2016; 21: 378-401. https://doi. org/10.1108/CDI-02-2015-0022

51. Walker AG. The Relationship between the Integration of Faith and Work with Life and Job Outcomes. J Bus Ethics. 2013; 112: 453-461. https://doi.org/10.1007/s10551-012-1271-0

52. Jabeen F, Friesen HL, Ghoudi K. Quality of work life of Emirati women and its influence on job satisfaction and turnover intention: Evidence from the UAE. J Organ Chang Manag. 2018; 31: 352-370. https://doi.org/10.1108/JOCM-01-2017-0016

53. Ho C-L, Au W-T. Teaching satisfaction scale: Measuring job satisfaction of teachers. Educ Psychol Meas. 2006; 66: 172-185. https://doi.org/10.1177/0013164405278573

54. Judge TA, Scott BA, llies R. Hostility, job attitudes, and workplace deviance: Test of a multilevel model. J Appl Psychol. 2006; 91: 126-138. https://doi.org/10.1037/0021-9010.91.1.126 PMID: 16435943

55. Viljevac A, Cooper-Thomas HD, Saks AM. An investigation into the validity of two measures of work engagement. Int J Hum Resour Manag. 2012; 23: 3692-3709. https://doi.org/10.1080/09585192. 2011.639542

56. Sinval J, Pasian SR, Queirós C, Marôco J. Brazil-Portugal transcultural adaptation of the UWES-9: Internal consistency, dimensionality, and measurement invariance. Front Psychol. 2018; 9: 1-18. https://doi.org/10.3389/fpsyg.2018.00001

57. Sinval J, Queirós C, Pasian SR, Marôco J. Transcultural adaptation of the Oldenburg Burnout Inventory (OLBI) for Brazil and Portugal. Front Psychol. 2019; 10: 1-28. https://doi.org/10.3389/fpsyg.2019. 00001

58. Lambert EG, Qureshi H, Frank J, Klahm C, Smith B. Job stress, job involvement, job satisfaction, and organizational commitment and their associations with job burnout among Indian police officers: A research note. J Police Crim Psychol. 2018; 33: 85-99. https://doi.org/10.1007/s11896-017-9236-y

59. Visser MRM, Smets EMA, Oort FJ, De Haes HCJM. Stress, satisfaction and burnout among Dutch medical specialists. C Can Med Assoc J. 2003; 168: 271-275. Available: http://www.cmaj.ca/content/ cmaj/168/3/271.full.pdf

60. Mijakoski D, Karadzinska-Bislimovska J, Basarovska V, Stoleski S, Minov J. Burnout and work demands predict reduced job satisfaction in health professionals working in a surgery clinic. Open Access Maced J Med Sci. 2015; 3: 166-173. https://doi.org/10.3889/oamjms.2015.020 PMID: 27275216

61. Saks AM. Antecedents and consequences of employee engagement. J Manag Psychol. 2006; 21: 600-619. https://doi.org/10.1108/02683940610690169

62. Saks AM, Gruman JA. What do we really know about employee engagement? Hum Resour Dev Q. 2014; 25: 155-182. https://doi.org/10.1002/hrdq.21187

63. Moura D, Orgambídez-Ramos A, Gonçalves G. Role stress and work engagement as antecedents of job satisfaction: Results from Portugal. Eur J Psychol. 2014; 10: 291-300. https://doi.org/10.5964/ ejop.v10i2.714

64. Locke EA. Construct validity vs. concept validity. Hum Resour Manag Rev. 2012; 22: 146-148. https:// doi.org/10.1016/j.hrmr.2011.11.008

65. Geisinger KF. The metamorphosis to test validation. Educ Psychol. 1992; 27: 197-222. https://doi.org/ 10.1207/s15326985ep2702_5

66. Bozionelos $\mathrm{N}$, Kostopoulos $\mathrm{K}$. What accounts for job satisfaction differences across countries? Acad Manag Perspect. 2010; 24: 82-84. https://doi.org/10.5465/AMP.2010.50304421

67. Huang T-P. Comparing motivating work characteristics, job satisfaction, and turnover intention of knowledge workers and blue-collar workers, and testing a structural model of the variables' relationships in China and Japan. Int J Hum Resour Manag. 2011; 22: 924-944. https://doi.org/10.1080/ 09585192.2011.555134

68. Masuda AD, Poelmans SAY, Allen TD, Spector PE, Lapierre LM, Cooper CL, et al. Flexible work arrangements availability and their relationship with work-to-family conflict, job satisfaction, and turnover intentions: A comparison of three country clusters. Appl Psychol An Int Rev. 2012; 61: 1-29. https://doi.org/10.1111/j.1464-0597.2011.00453.x 
69. Chiu RK, Kosinsk FA. The role of affective dispositions in job satisfaction and work strain: Comparing collectivist and individualist societies. Int J Psychol. 1999; 34: 19-28. https://doi.org/10.1080/ 002075999400078

70. Pichler F, Wallace $\mathrm{C}$. What are the reasons for differences in job satisfaction across Europe individual, compositional, and institutional explanations. Eur Sociol Rev. 2009; 25: 535-549. https://doi.org/10. 1093/esr/jcn070

71. Hauff S, Richter NF, Tressin T. Situational job characteristics and job satisfaction: The moderating role of national culture. Int Bus Rev. 2015; 24: 710-723. https://doi.org/10.1016/j.ibusrev.2015.01.003

72. Huang $X$, Van De Vliert $E$. Where intrinsic job satisfaction fails to work: National moderators of intrinsic motivation. J Organ Behav. 2003; 24: 159-179. https://doi.org/10.1002/job.186

73. Adigun IO, Stephenson GM. Sources of job motivation and satisfaction among British and Nigerian employees. J Soc Psychol. 1992; 132: 369-376. https://doi.org/10.1080/00224545.1992.9924712

74. Tabvuma V, Georgellis $\mathrm{Y}$, Lange $\mathrm{T}$. Orientation training and job satisfaction: A sector and gender analysis. Hum Resour Manage. 2015; 54: 303-321. https://doi.org/10.1002/hrm.21650

75. Georgellis Y, Lange T, Tabvuma V. The impact of life events on job satisfaction. J Vocat Behav. 2012; 80: 464-473. https://doi.org/10.1016/j.jvb.2011.12.005

76. Hakim C. Grateful slaves and self-made women: Fact and fantasy in women's work orientations. Eur Sociol Rev. 1991; 7: 101-121. https://doi.org/10.1093/oxfordjournals.esr.a036590

77. Tait M, Padgett MY, Baldwin TT. Job and life satisfaction: A reevaluation of the strength of the relationship and gender effects as a function of the date of the study. J Appl Psychol. 1989; 74: 502-507. https://doi.org/10.1037/0021-9010.74.3.502

78. Associação Brasileira de Empresas de Pesquisa. Critério de classificação econômica do Brasil [Criteria for economic classification in Brazil] [Internet]. 2012. Available: http://www.abep.org/

79. International Labour Office. International Standard Classification of Occupations. Isco-08. Geneva, Switzerland: International Labour Organization; 2012. https://doi.org/10.13140/RG.2.1.1419.3126

80. LimeSurvey GmbH. LimeSurvey: An open source survey tool [Computer software] [Internet]. Hamburg, Germany: Author; 2019. Available: http://www.limesurvey.org

81. Judge TA, Klinger R. Job satisfaction: Subjective well-being at work. In: Eid M, Larsen RJ, editors. The science of subjective well-being. New York, NY: Guilford Press; 2008. pp. 393-413.

82. Judge TA, Erez A, Bono JE, Thoresen CJ. The Core Self-Evaluations Scale: Development of a measure. Pers Psychol. 2003; 56: 303-331. https://doi.org/10.1111/j.1744-6570.2003.tb00152.x

83. International Test Commission. ITC Guidelines for Translating and Adapting Tests (second edition). Int J Test. 2018; 18: 101-134. https://doi.org/10.1080/15305058.2017.1398166

84. Sinval J, Sirgy MJ, Lee D-J, Marôco J. The Quality of Work Life Scale: Validity evidence from Brazil and Portugal. Appl Res Qual Life. 2019; https://doi.org/10.1007/s11482-019-09730-3

85. World Health Organization. International classification of diseases for mortality and morbidity statistics [Internet]. 11th rev. 2018. Available: https://icd.who.int/browse11/l-m/en

86. Demerouti E, Bakker AB, Vardakou I, Kantas A. The convergent validity of two burnout instruments: A multitrait-multimethod analysis. Eur J Psychol Assess. 2003; 19: 12-23. https://doi.org/10.1027// 1015-5759.19.1.12

87. Schaufeli WB, Salanova M, González-Romá V, Bakker AB. The measurement of engagement and burnout: A two sample confirmatory factor analytic approach. J Vocat Behav. 2002; 3: 71-92. https:// doi.org/10.1023/A:1015630930326

88. Bakker AB, Demerouti E. Towards a model of work engagement. Career Dev Int. 2008; 13: 209-223. https://doi.org/10.1108/13620430810870476

89. Rodrigues S, Sinval J, Queirós C, Marôco J, Kaiseler M. Transitioning from recruit to officer: An investigation of how stress appraisal and coping influence work engagement. Int J Sel Assess. 2019; 27: 152-168. https://doi.org/10.1111/ijsa.12238

90. Sinval J, Marques-Pinto A, Queirós C, Marôco J. Work engagement among rescue workers: Psychometric properties of the Portuguese UWES. Front Psychol. 2018; 8: 1-16. https://doi.org/10.3389/ fpsyg.2017.02229 PMID: 29403403

91. R Core Team. R: A language and environment for statistical computing (version 3.6.1) [Computer software] [Internet]. Vienna, Austria: R Foundation for Statistical Computing; 2019. Available: https:// www.r-project.org/

92. RStudio Team. RStudio: Integrated development for R (version 1.2.1330) [Computer software] [Internet]. Boston, MA, USA: RStudio, Inc.; 2019. Available: http://www.rstudio.com/ 
93. McNamara A, Arino de la Rubia E, Zhu H, Ellis S, Quinn M. skimr: Compact and flexible summaries of data (R package version 1.0.3) [Computer software] [Internet]. 2018. Available: https://cran.r-project. org/package=skimr

94. Mardia KV. Measures of multivariate skewness and kurtosis with applications. Biometrika. 1970; 57: 519-530. https://doi.org/10.1093/biomet/57.3.519

95. Revelle W. psych: Procedures for psychological, psychometric, and personality research (R package version 1.9.4) [Computer software] [Internet]. Evanston, IL: Northwestern University; 2019. Available: https://cran.r-project.org/package=psych

96. Rosseel Y. lavaan: An R package for structural equation modeling. J Stat Softw. 2012; 48: 1-21. https://doi.org/10.18637/jss.v048.i02

97. Muthén BO. Latent variable structural equation modeling with categorical data. J Econom. 1983; 22: 43-65. https://doi.org/10.1016/0304-4076(83)90093-3

98. Hu L, Bentler PM. Cutoff criteria for fit indexes in covariance structure analysis: Conventional criteria versus new alternatives. Struct Equ Model A Multidiscip J. 1999; 6: 1-55. https://doi.org/10.1080/ 10705519909540118

99. Byrne BM. Structural Equation Modeling with AMOS [Internet]. 3rd ed. New York, NY, USA: Routledge; 2010. https://doi.org/10.4324/9781410600219

100. Marôco J. Análise de equações estruturais: Fundamentos teóricos, software \& aplicações. 2nd ed. Pêro Pinheiro, Portugal: ReportNumber; 2014.

101. Fornell C, Larcker DF. Evaluating structural equation models with unobservable variables and measurement error. J Mark Res. 1981; 18: 39-50. https://doi.org/10.2307/3151312

102. Jorgensen TD, Pornprasertmanit S, Schoemann AM, Rosseel Y. semTools: Useful tools for structural equation modeling (R package version 0.5-1.933) [Computer software] [Internet]. 2019. Available: https://cran. r-project.org/package=semTools

103. Cronbach LJ. Coefficient alpha and the internal structure of tests. Psychometrika. 1951; 16: 297-334. https://doi.org/10.1007/BF02310555

104. Raykov T. Estimation of congeneric scale reliability using covariance structure analysis with nonlinear constraints. Br J Math Stat Psychol. 2001; 54: 315-323. https://doi.org/10.1348/000711001159582 PMID: 11817096

105. Bollen KA. Issues in the comparative measurement of political democracy. Am Sociol Rev. 1980; 45: 370-380. https://doi.org/10.2307/2095172

106. Millsap RE, Yun-Tein J. Assessing factorial invariance in ordered-categorical measures. Multivariate Behav Res. 2004; 39: 479-515. https://doi.org/10.1207/S15327906MBR3903_4

107. Cohen J. Statistical power analysis for the behavioral sciences. 2nd ed. Hillsdale, NJ, USA: Lawrence Erlbaum Associates; 1988.

108. Højsgaard S, Halekoh U. doBy: Groupwise statistics, LSmeans, linear contrasts, utilities (R package version 4.6-2) [Computer software] [Internet]. 2018. Available: https://cran.r-project.org/package= doBy

109. Cramér H. Mathematical methods of statistics. Princeton, NJ, USA: Princeton University Press; 1946. https://doi.org/10.2307/2332454

110. Yule GU. On the methods of measuring association between two attributes. J R Stat Soc. 1912; 75 : 579-652. https://doi.org/10.2307/2340126

111. Navarro D. Learning statistics with $R$ : A tutorial for psychology students and other beginners (R package version 0.5) [Internet]. Adelaide, Australia: University of Adelaide; 2015. Available: https://cran.rproject.org/package=Isr

112. Finney SJ, DiStefano C. Non-normal and categorical data in structural equation modeling. In: Hancock GR, Mueller RO, editors. Structural equation modeling: A second course. 2nd ed. Charlotte, NC, USA: Information Age Publishing; 2013. pp. 439-492.

113. Cheung GW, Rensvold RB. Evaluating goodness-of-fit indexes for testing measurement invariance. Struct Equ Model A Multidiscip J. 2002; 9: 233-255. https://doi.org/10.1207/S15328007SEM0902_5

114. Satorra A, Bentler PM. A scaled difference chi-square test statistic for moment structure analysis. Psychometrika. 2001; 66: 507-514. https://doi.org/10.1007/BF02296192

115. Kline RB. Principles and practice of structural equation modeling. 4th ed. New York, NY, USA: The Guilford Press; 2016.

116. De Simone S, Planta A, Cicotto G. The role of job satisfaction, work engagement, self-efficacy and agentic capacities on nurses' turnover intention and patient satisfaction. Appl Nurs Res. 2018; 39: 130-140. https://doi.org/10.1016/j.apnr.2017.11.004 PMID: 29422148 
117. Rafferty AE, Griffin MA. Job satisfaction in organizational research. In: Buchanan DA, Bryman A, editors. The SAGE handbook of organizational research methods. London, UK: SAGE; 2009. pp. 196212.

118. Suárez-Alvarez J, Pedrosa I, Lozano LM, García-Cueto E, Cuesta M, Muñiz J. Using reversed items in Likert scales: A questionable practice. Psicothema. 2018; 30: 149-158. https://doi.org/10.7334/ psicothema2018.33 PMID: 29694314

119. Schriesheim CA, Eisenbach RJ. An exploratory and confirmatory factor-analytic investigation of item wording effects on the obtained factor structures of survey questionnaire measures. J Manage. 1995; 21: 1177-1193. https://doi.org/10.1016/0149-2063(95)90028-4

120. Schmitt N, Stults DM. Factors defined by negatively keyed items: The result of careless respondents? Appl Psychol Meas. 1985; 9: 367-373. https://doi.org/10.1177/014662168500900405

121. Chen FF, Sousa KH, West SG. Teacher's corner: Testing measurement invariance of second-order factor models. Struct Equ Model A Multidiscip J. 2005; 12: 471-492. https://doi.org/10.1207/ s15328007sem1203_7

122. Figueiredo-Ferraz H, Grau-Alberola E, Gil-Monte PR, García-Juesas JA. Burnout and job satisfaction among nursing professionals. Psicothema. 2012; 24: 271-276. Available: https://www.scopus.com/ inward/record. uri?eid=2-s2.0-84858306319\&partnerID=40\&md5= 460d727bb59573b7ea31e61967eea643 PMID: 22420356

123. Lewig KA, Dollard MF. Emotional dissonance, emotional exhaustion and job satisfaction in call centre workers. Eur J Work Organ Psychol. 2003; 12: 366-392. https://doi.org/10.1080/13594320344000200

124. Khamisa N, Oldenburg B, Peltzer K, llic D. Work related stress, burnout, job satisfaction and general health of nurses. Int J Environ Res Public Health. 2015; 12: 652-666. https://doi.org/10.3390/ ijerph120100652 PMID: 25588157

125. Orgambídez-Ramos $\mathrm{A}$, de Almeida $\mathrm{H}$. Work engagement, social support, and job satisfaction in Portuguese nursing staff: A winning combination. Appl Nurs Res. 2017; 36: 37-41. https://doi.org/10.1016/j. apnr.2017.05.012 PMID: 28720237

126. Garg K, Dar IA, Mishra M. Job satisfaction and work engagement: A study using private sector bank managers. Adv Dev Hum Resour. 2018; 20: 58-71. https://doi.org/10.1177/1523422317742987

127. Karanika-Murray M, Duncan N, Pontes HM, Griffiths MD. Organizational identification, work engagement, and job satisfaction. J Manag Psychol. 2015; 30: 1019-1033. https://doi.org/10.1108/JMP-112013-0359

128. Shimazu A, Schaufeli WB. Is workaholism good or bad for employee well-being? The distinctiveness of workaholism and work engagement among Japanese employees. Ind Health. 2009; 47: 495-502. Available: http://www.ncbi.nlm.nih.gov/pubmed/19834258 https://doi.org/10.2486/indhealth.47.495 PMID: 19834258

129. Mora JG, García-Aracil A, Vila LE. Job satisfaction among young European higher education graduates. High Educ. 2007; 53: 29-59. https://doi.org/10.1007/s10734-005-2377-4

130. Kristensen $\mathrm{N}$, Johansson $\mathrm{E}$. New evidence on cross-country differences in job satisfaction using anchoring vignettes. Labour Econ. 2008; 15: 96-117. https://doi.org/10.1016/j.labeco.2006.11.001

131. Davidov E, Meuleman B, Cieciuch J, Schmidt $P$, Billiet J. Measurement equivalence in cross-national research. Annu Rev Sociol. 2014; 40: 55-75. https://doi.org/10.1146/annurev-soc-071913-043137

132. Ishara S, Bandeira M, Zuardi AW. Public psychiatric services: Job satisfaction evaluation. Rev Bras Psiquiatr. 2007; 30: 38-41. https://doi.org/10.1590/s1516-44462006005000064 PMID: 18176729

133. Diaz-Serrano L, Vieira $\mathrm{J}$ a $\mathrm{C}$. Low pay, higher pay and job satisfaction within the European Union: Empirical evidence from fourteen countries. IZA Discuss Pap. 2005; 1-25. Available: http://ssrn.com/ abstract $=702889$

134. Sousa-Poza A, Sousa-Poza AA. Taking another look at the gender/job-satisfaction paradox. Kyklos. 2000; 53: 135-152. https://doi.org/10.1111/1467-6435.00114

135. Kaiser LC. Gender-job satisfaction differences across Europe: An indicator for labour market modernization. Int J Manpow. 2007; 28: 75-94. https://doi.org/10.1108/01437720710733483

136. Cheung C-K, Scherling SA. Job satisfaction, work values, and sex differences in Taiwan's organizations. J Psychol. 1999; 133: 563-575. https://doi.org/10.1080/00223989909599763 PMID: 10507141

137. Sauser WI, York CM. Sex differences in job satisfaction: A re-examination. Pers Psychol. 1978; 31: 537-547. https://doi.org/10.1111/j.1744-6570.1978.tb00461.x

138. Moreno-Jiménez MP, Ríos-Rodríguez ML, Canto-Ortiz J, Martín-García JS, Perles-Nova F. Job satisfaction and burnout in low-skilled jobs: Sex differences on the immigrant population. Rev Psicol del Trab y las Organ. 2010; 26: 255-265. https://doi.org/10.5093/tr2010v26n3a8 
139. Eskildsen JK, Kristensen K, Westlund AH. Work motivation and job satisfaction in the Nordic countries. Empl Relations. 2004; 26: 122-136. https://doi.org/10.1108/01425450410511043

140. Zou M. Gender, work orientations and job satisfaction. Work Employ Soc. 2015; 29: 3-22. https://doi. org/10.1177/0950017014559267

141. Emanuel F, Molino M, Presti A Lo, Spagnoli P, Ghislieri C. A crossover study from a gender perspective: The relationship between job insecurity, job satisfaction, and partners' family life satisfaction. Front Psychol. 2018; 9: 1-10. https://doi.org/10.3389/fpsyg.2018.00001

142. Hodson R. Gender differences in job satisfaction: Why aren't women more dissatisfied? Sociol Q. 1989; 30: 385-399. https://doi.org/10.1111/j.1533-8525.1989.tb01527.x

143. Hulin CL, Smith PC. Sex differences in job satisfaction. J Appl Psychol. 1964; 48: 88-92. https://doi. org/10.1037/h0040811

144. Blau FD, Brinton MC, Grusky DB, editors. The declining significance of gender? New York, NY, USA: Russell Sage Foundation; 2006. https://doi.org/10.7758/9781610440622

145. Blau FD, Winkler AE. The economics of women, men, and work. 8th ed. New York, NY, USA: Oxford University Press; 2018.

146. Stride C, Wall TD, Catley N. Measures of job satisfaction, organisational commitment, mental health and job-related well-being: A benchmarking manual. 2nd ed. Chichester, UK: John Wiley \& Sons; 2007.

147. Meade AW, Craig SB. Identifying careless responses in survey data. Psychol Methods. 2012; 17: 437-455. https://doi.org/10.1037/a0028085 PMID: 22506584

148. Berry DTR, Wetter MW, Baer RA, Larsen L, Clark C, Monroe K. MMPI-2 random responding indices: Validation using a self-report methodology. Psychol Assess. 1992; 4: 340-345. https://doi.org/10. 1037/1040-3590.4.3.340

149. Liu Y, Millsap RE, West SG, Tein J-Y, Tanaka R, Grimm KJ. Testing measurement invariance in longitudinal data with ordered-categorical measures. Psychol Methods. 2017; 22: 486-506. https://doi.org/ 10.1037/met0000075 PMID: 27213981 